\title{
Intestinal malrotation and acute left side appendicitis: an indication for laparoscopic exploration
}

\author{
Cristina Sedano-Vizcaíno, ${ }^{1}$ Andre Goulart, ${ }^{2}$ Carlos Moreno-Sanz, ${ }^{1}$ \\ Francisco Sánchez-De Pedro ${ }^{1}$
}

${ }^{1}$ Department of General Surgery, Hospital La Mancha Centro, Alcázar de San Juan, Spain

${ }^{2}$ Department of General Surgery, Hospital de Braga, Braga, Portugal

\section{Correspondence to} Dr Cristina Sedano-Vizcaíno, crisedano@hotmail.com

Accepted 8 April 2015

\section{DESCRIPTION}

A 67-year-old woman with a medical history of arterial hypertension was admitted to the emergency department with 1-day evolution of abdominal pain. The patient presented continuous pain at the lower abdomen associated with nausea and vomiting.

On physical examination, she had pain without tenderness at the lower abdomen. Laboratory tests showed an elevated white cell count (15 900/ $\mathrm{LL}$ with left shift) and a $\mathrm{C}$ reactive protein level of $17.2 \mathrm{mg} / \mathrm{dL}$ (normal range $<0.5 \mathrm{mg} / \mathrm{dL}$ ). A chest and abdominal X-ray did not show any alterations. A CT scan with intravenous and oral contrast was performed, and showed findings of complete intestinal malrotation with the entire colon shifted to the left and small bowel moved to the right (figure 1A). The caecum was positioned at the lower pelvis, and the appendix presented dilation and thickening with small bubbles of extraluminal air, and had a small quantity of liquid at the Douglas pouch, suggestive of acute perforated appendicitis (figure $1 \mathrm{~B}, \mathrm{C}$ ).

The patient underwent exploratory laparoscopy. The complete intestinal malrotation was confirmed, and a gangrenous and perforated appendix with small quantity of purulent fluid was observed at the left of the pelvis (figure 2A). Laparoscopic appendectomy was performed with the base of the appendix double ligated with Endoloop Ligature (polyglactin 910, Ethicon) on healthy tissue (figure 2B). The appendix was removed with a laparoscopic bag and toilet peritoneal lavage performed. The postoperative period was complicated by an $8 \mathrm{~mm} \times 17 \mathrm{~mm}$ abdominal abscess treated with percutaneous drainage and antibiotics.

True left-sided acute appendicitis develops in association with two types of congenital anomalies: situs inversus and intestinal malrotation. ${ }^{1}$ Intestinal malrotation is a congenital positional anomaly of the intestine caused by non-rotation or incomplete rotation of the primitive loop around the axis of the superior mesenteric artery. ${ }^{1}$ Malrotation occurs in one of every 500 births; most cases of malrotation are detected by 1 year of age and the true incidence in adults is unknown. ${ }^{2}$

A review from 2010 encountered 95 published cases of left-sided appendicitis, with only 23 associated with intestinal malrotation. ${ }^{1}$ Laparoscopic appendectomies for acute appendicitis associated
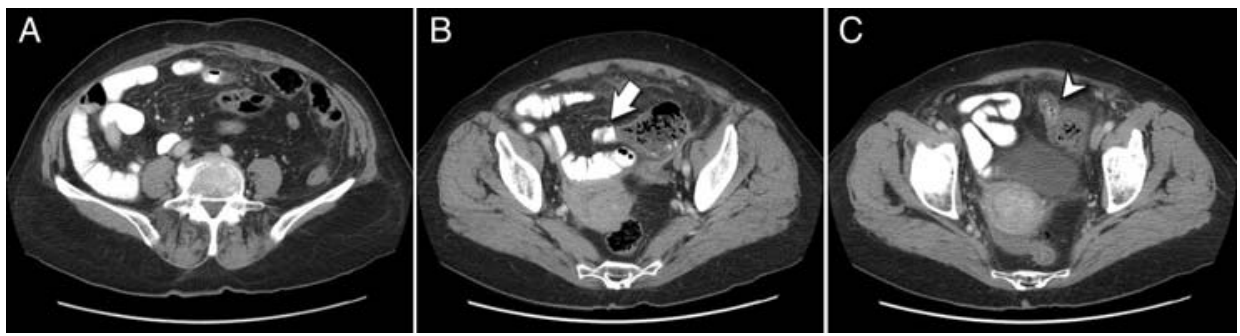

Figure 1 (A) CT scan showing complete intestinal malrotation with the entire colon shifted to the left and small bowel (with oral contrast) moved to the right. (B) Caecum positioned at the lower pelvis (arrow pointing to terminal ileum). (C) Appendix presented dilation and thickening suggestive of acute perforated appendicitis (arrowhead pointing to appendix).
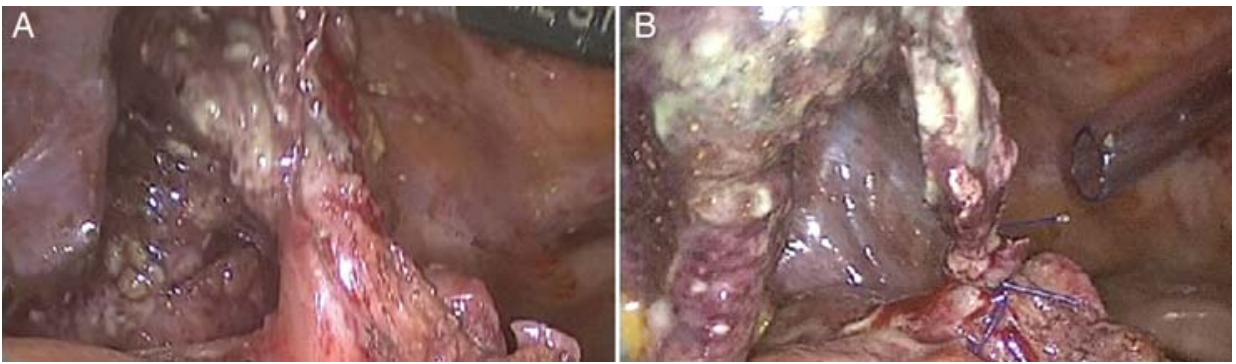

Figure 2 Intraoperative findings: (A) gangrenous and perforated appendix with healthy tissue at the base and (B) ligation of appendiceal stump with endoloops. 
with intestinal malrotation are even rarer, with only 15 cases described until 2014. ${ }^{2}$

The surgeon is generally trained to perform a right-sided appendectomy. An intestinal malrotation places the appendix on the left side or deep in the pelvis, which adds difficulty to the surgical procedure and, if performed by laparotomy, may require a large incision. The laparoscopic approach has several established benefits and the operative costs can be reduced using low-cost devices such as endoloops for ligation of the appendiceal stump, which can be safely used even in complicated appendicitis, as demonstrated by other authors. ${ }^{3}$ In this

\section{Learning points}

Acute appendicitis is a differential diagnosis of lower left abdominal pain.

- In a case of acute left-sided appendicitis, laparoscopic approach is the gold standard. setting, laparoscopy has the benefits of being diagnostic and therapeutic, as well as having a less invasive approach.

Contributors CS-V conceived of the study, drafted the manuscript and approved the final version. AG drafted the manuscript and approved the final version. CM-S critically revised the manuscript for important intellectual content and approved the final version. FS-DP conceived of the study, critically revised the manuscript for important intellectual content and approved the final version.

Competing interests None declared.

Patient consent Obtained.

Provenance and peer review Not commissioned; externally peer reviewed.

\section{REFERENCES}

1 Akbulut S, Ulku A, Senol A, et al. Left-sided appendicitis: review of 95 published cases and a case report. World J Gastroenterol 2010;16:5598-602.

2 Tsukada T, Kaji M, Higashi Y, et al. Single-incision laparoscopic appendectomy for treating appendicitis in a patient with gastrointestinal malrotation. Int I Surg Case Rep 2014;5:558-61.

3 Di Saverio S, Mandrioli M, Sibilio A, et al. A cost-effective technique for laparoscopic appendectomy: outcomes and costs of a case-control prospective single-operator study of 112 unselected consecutive cases of complicated acute appendicitis. J Am Coll Surg 2014;218:e51-65.

Copyright 2015 BMJ Publishing Group. All rights reserved. For permission to reuse any of this content visit http://group.bmj.com/group/rights-licensing/permissions.

BMJ Case Report Fellows may re-use this article for personal use and teaching without any further permission.

Become a Fellow of BMJ Case Reports today and you can:

- Submit as many cases as you like

- Enjoy fast sympathetic peer review and rapid publication of accepted articles

- Access all the published articles

- Re-use any of the published material for personal use and teaching without further permission

For information on Institutional Fellowships contact consortiasales@bmjgroup.com

Visit casereports.bmj.com for more articles like this and to become a Fellow 